\title{
Triterpenoids mediate the antimicrobial, antioxidant, and anti-inflammatory activities of the stem bark of Reissantia indica
}

\author{
Gina Flor Ramos ${ }^{1}$, Isaac Kingsley Amponsah² ${ }^{2}$, Benjamin Kingsley Harley², Yakubu Jibira ${ }^{4}$, Michael Kwesi Baah ${ }^{5}$, \\ Silas Adjei ${ }^{5}$, Francis Ackah Armah ${ }^{6}$, Abraham Yeboah Mensah ${ }^{2}$ \\ ${ }^{1}$ Department of Pharmacognosy, Faculty of Pharmacy, Madonna University, Elele, Nigeria. \\ ${ }^{2}$ Department of Pharmacognosy, Faculty of Pharmacy and Pharmaceutical Sciences, KNUST, Kumasi, Ghana. \\ ${ }^{3}$ Department of Pharmacognosy and Herbal Medicine, School of Pharmacy, University of Health and Allied Sciences, Ho, Ghana. \\ ${ }^{4}$ Department of Pharmacology, Faculty of Pharmacy and Pharmaceutical Sciences, College of Health Sciences, KNUST, Kumasi, Ghana. \\ ${ }^{5}$ Department of Herbal Medicine, Faculty of Pharmacy and Pharmaceutical Sciences, College of Health Sciences, KNUST, Kumasi, Ghana. \\ ${ }^{6}$ Department of Biomedical Sciences, School of Allied Health Sciences, University of Cape Coast, Cape Coast, Ghana.
}

\section{ARTICLE INFO \\ Received on: 29/09/2020 \\ Accepted on: 16/01/2021 \\ Available online: 05/05/2021}

Key words:

Arjunolic acid, inflammation, microbes, antioxidants, structure elucidation sitosterol.

\begin{abstract}
Reissantia indica (Willd.) Halle is employed widely in African folklore medicine for the mitigation of inflammatory conditions and certain cancers. However, scientific validation of its anecdotal uses is not widespread. The study validated the antimicrobial, antioxidant, and anti-inflammatory activities of the stem bark of $R$. indica and tracked down its active constituents. The anti-inflammatory activity of the hydroethanolic stem bark extract and isolates was evaluated using the 7-day-old chick edema model with carrageenan as the edemogenic agent. Antioxidant activity was carried out by the 2,2-diphenyl-1-picrylhydrazyl (DPPH) scavenging and total antioxidant capacity assays. Antimicrobial activity was carried out by the broth dilution method, using some Gram-negative and Gram-positive organisms. The stem bark extract and reference drug diclofenac showed a dose-dependent anti-inflammatory effect with respective $\mathrm{ED}_{50}$ of $33.02 \pm 3.66$ and $20.49 \pm 2.26 \mathrm{mg} / \mathrm{kg}$ body weight. The stem bark extract showed considerably higher activities in the antioxidant and antimicrobial assays than sitosterol and arjunolic acid, isolated from $R$. indica. The plant demonstrates significant anti-inflammatory, antimicrobial, and antioxidant properties as suggested by folklore medicine.
\end{abstract}

\section{INTRODUCTION}

The immune system elicits an inflammatory cascade in response to harmful agents such as microorganisms, oxidative stress, toxins, radiations, and tissue injury (Medzhitov, 2010) aimed at healing (Ferrero-Miliani et al., 2007). The inflammatory response is, therefore, crucial to maintaining good health. To reduce inflammation, the offending agent has to be removed otherwise it will result in uncontrolled inflammation. Uncontrolled inflammation may become chronic, resulting in several inflammatory conditions such as obesity, type 2 diabetes, atherosclerosis, eye disorders,

\footnotetext{
"Corresponding Author

Isaac Kingsley Amponsah, Department of Pharmacognosy, Faculty of Pharmacy and Pharmaceutical Sciences, KNUST, Kumasi, Ghana.

E-mail: akila.amponsah@gmail.com
}

cardiovascular diseases, autoimmune diseases, Alzheimer's, arthritis, cancers, and inflammatory bowel disease (Sugimoto et al., 2016; Zhou et al., 2016). Poorly controlled inflammation may occur when infections are not well managed by host defense mechanisms or through the irrational use of conventional antimicrobials (EavesPyles et al., 2008).

These infections are caused by microorganisms such as viruses, bacteria, and fungi. The mammalian hosts react to infections with an innate response, often involving inflammation. It is hypothesized that chronic infections induce persistent inflammation which lends support to the development of inflammatory-related disorders (Xie et al., 2017). Another factor that leads to uncontrolled inflammation is oxidative stress, a disproportion between reactive oxygen free radical generation or formation and the protective endogenous antioxidant system. The resultant oxidative stress condition leads to the damage or 
destruction of vital cellular components including membrane lipids, proteins, and DNA. Ultimately, cell death may be the end result (Tandon et al., 2005), culminating in the emergence of cancer, ischemia, anemia, degenerative and cardiovascular diseases (Ravipati et al., 2012).

Thus, the treatment of inflammatory conditions may require a multifaceted approach involving other agents directed toward the source of the inflammation. Despite their proven efficacy in alleviating inflammatory symptoms and providing relief, all conventional therapeutic agents have many adverse reactions and side effects. Anti-inflammatory drugs (steroidal and nonsteroidal) are documented to cause significant renal and gastrointestinal damage, among other side effects (Guardia et al., 2001; Kidd and Urban, 2001). This peculiar challenge with conventional anti-inflammatory agents has stimulated research interest for alternative agents. The search for new drug candidates that can provide immunity against free radicalmediated oxidative destruction and prevent the development of inflammation-related complications has brought medicinal plants into focus as a repository of a number of invaluable antioxidant molecules (Angiolella et al., 2018), as well as a potential source of novel antimicrobial agents (Cowan, 1999). Plant-based remedies have been used for centuries to reduce pain and inflammation. They have been documented to inhibit inflammatory pathways like those of non-steroidal anti-inflammatory drugs (NSAIDs). They are known to inhibit the cyclooxygenase and nuclear factor$\mathrm{kB}$ inflammatory pathways. Their use is popular in developing countries due to the ease of availability, accessibility, and cost (Okoye et al., 2014). One such plant is Reissantia indica (Willd.) Halle of the family Celastraceae. The plant is used in traditional medicine for inflammatory conditions, infections, and cancers (Mshana et al., 2000). A number of these traditional claims have not been validated. Pharmacological reports on $R$. indica are not widespread. Elsewhere, human breast cancer cell lines at $100 \mu \mathrm{g} /$ $\mathrm{ml}$ was inhibited by ethanolic extract of the stem bark (Gayathri et al., 2018). The present research evaluated the antioxidant, antimicrobial, and anti-inflammatory properties of stem bark extract and some isolated triterpenoids from $R$. indica.

\section{MATERIALS AND METHODS}

\section{Plant material collection, authentication, and extraction}

The fresh stem bark of $R$. indica was harvested from the tropical forest of Kwahu Asakraka, in the Eastern part of Ghana, and authenticated at the Department of Herbal Medicine, Faculty of Pharmacy and Pharmaceutical Sciences, College of Health Sciences, Kwame Nkrumah University of Science and Technology (KNUST), Kumasi, Ghana, where a sample is kept (herbarium number KNUST/HM1/SB114).

The plant material was cleaned of extraneous matter, dried under the shade for 7 days, and milled into coarse powder. Extraction was carried out by cold maceration using hydroethanol $(70 \% \mathrm{v} / \mathrm{v})$ and reduced into a brown mass at $60^{\circ} \mathrm{C}$ in vacuo using a rotary evaporator (Model: Rotavapor R-215, BÜCHI Labortechnik AG, Flawil, Switzerland). Drying was continued on a water bath for 48 hours and kept in a refrigerator until required for use. This extract obtained was designated as RE.

\section{Chemicals and reagents}

Clotrimazole, ascorbic acid, and diclofenac sodium were obtained from Gihoc Phyto-Riker, Accra, Ghana. Ciprofloxacin (Denk Pharma, Germany), nutrient broth, nutrient agar (Oxoid Ltd., Basingstoke, UK). 5-diphenyltetrazolium bromide [3-(4,5-Dimethylthiazol-2-yl)-2,5-Diphenyltetrazolium Bromide, 97\%], DPPH radical (98\%), ammonium molybdate (99.9\%), and carrageenan were obtained from Sigma-Aldrich Inc., St. Louis, MO.

\section{Microorganisms used for the antimicrobial assay}

The clinical strains of Streptococcus pneumonia, Staphylococcus aureus, Klebsiella pneumoniae, Escherichia coli, Enterococcus faecalis, Pseudomonas aeruginosa, Salmonella typhi, Candida albicans were acquired from the Department of Applied and Theoretical Science, College of Science, KNUSTKumasi, Ghana. The microorganisms were kept on $20 \mathrm{ml}$ slants of nutrient agar with glycerol $(30 \%)$ at $-4^{\circ} \mathrm{C}$.

\section{Animals for the anti-inflammatory assay}

Gallus gallus (strain: Shaver 579), 1-day post-hatch, was purchased from Akati Farms, Kumasi, Ghana, and kept in stainless steel cages of dimensions; $34 \times 57 \times 40 \mathrm{~cm}$, with a population of 10 cockerels per cage. Animals had access to chick mash (standard poultry feed, GAFCO, Ghana) and clean water. The vivarium temperature was kept at about $29^{\circ} \mathrm{C} \pm 1{ }^{\circ} \mathrm{C}$ and a 12 -hour light-dark cycle was maintained using overhead incandescent illumination. Daily cage maintenance was carried out and the chicks were checked daily for weight and good health until the 7 th day when they were tested. The experiment was carried out under guidelines provided by the National Institute of Health for Care and Use of Laboratory Animals (NIH, publication number: 83-23, revised 1985; Committee, 2011) and was approved by the Department of Pharmacology Ethics Committee, KNUSTKumasi, Ghana.

\section{Antioxidant assays}

\section{$D P P H$ radical scavenging assay}

The DPPH free radical scavenging activity of $R$. indica stem bark extract (RE), isolates, and the reference antioxidant compound, ascorbic acid were evaluated using the standard protocol previously described by Govindappa et al. (2011). RE (1,000 $\mu$ l each) was tested between 7.8 and $500 \mu \mathrm{g} \mathrm{ml}^{-1}$, whereas ascorbic acid and the isolated compounds RF1 and RF12 were tested between 10 and $100 \mu \mathrm{g} \mathrm{ml}^{-1}$ prepared by two-fold dilution and subsequently mixed with $3,000 \mu \mathrm{l}$ of DPPH $(0.002 \%$ DPPH in methanol). Incubation of the mixture was carried out in the dark for 30 minutes and absorbance was measured at $517 \mathrm{~nm}$ on a Cecil CE 7,200 spectrophotometer (Cecil Instrument Limited, England). A solution of methanol in DPPH served as the negative control. The radical scavenging activity was calculated using the following equation:

$$
\% \text { DPPH inhibition }=\left\|1-\left[\frac{A_{\text {agent }}}{A_{\text {control }}}\right] \times 100\right\|
$$

where $A_{\text {agent }}$ denotes absorbance for the extract or the reference agent and $A_{\text {control }}$ denotes absorbance of the control. 


\section{Phosphomolybdenum antioxidant assay}

The total antioxidant capacity assay was carried out as reported by Prieto et al. (1999) with slight modification. One mL of $\mathrm{RE}\left(500-7.81 \mu \mathrm{g} \mathrm{ml}^{-1}\right.$ ) was added to $3 \mathrm{ml}$ of a mixture (containing $4 \mathrm{mM}$ of ammonium molybdate, $28 \mathrm{mM}$ disodium hydrogen phosphate, and $6 \mathrm{mM}$ sulfuric acid) and incubated for 90 minutes at $95^{\circ} \mathrm{C}$. The mixture was cooled and about $200 \mu \mathrm{l}$ transferred into a microtitre plate and the optical density was measured at 695 $\mathrm{nm}$. The experiment was repeated with the reference compound, ascorbic acid (100-3.13 $\left.\mu \mathrm{g} \mathrm{ml}^{-1}\right)$, which was subsequently used to develop a calibration curve. Triplicate experiment was carried out and the results were presented as ascorbic acid equivalent (AAE) in $\mathrm{mg}$ per $\mathrm{g}$ of $R$. indica extract. The isolated compounds RF1 and RF12 were tested at $50 \mu \mathrm{g} \mathrm{ml}^{-1}$.

\section{Antimicrobial assay}

\section{Preparation of the inoculum}

The bacteria were activated by inoculating $20 \mu \mathrm{l}$ of the respective stock strains/isolates in single strength nutrient broth and incubated for 24 hours at $37^{\circ} \mathrm{C}$. These culture suspensions were serially diluted with sterile water to achieve initial cell counts of approximately $1 \times 10^{5}$ colony forming unit, CFU/ml (Elkhair et al., 2010).

\section{Broth microdilution method}

The microdilution method was used in the determination of the minimum inhibitory concentration (MIC) of the extracts (Cos et al., 2006). Sample stock solutions were prepared in sterile water to achieve in-well concentrations of $0.156-20 \mathrm{mg} / \mathrm{ml}$. A hundred microliters of double-strength nutrient broth, $20 \mu \mathrm{l}$ of the inoculum, and $100 \mu \mathrm{l}$ of stock extract solution were added to the test wells. Two hundred microliters of double-strength nutrient broth containing $20 \mu \mathrm{l}$ of the test organisms served as the control. Solution of $10 \mu \mathrm{l}$ sterile water, $100 \mu \mathrm{l}$ double-strength nutrient broth, and $100 \mu \mathrm{l}$ extract was used as blank. The microtitre plates were incubated at $37^{\circ} \mathrm{C}$ for 24 hours. Ciprofloxacin was used as reference drug for the antibacterial assay, whereas clotrimazole served as the reference agent for the antifungal test. Absence of visible growth in a particular test well compared to the negative control well, where there is obvious growth as determined with tetrazolium salts, was taken as the MIC.

\section{Anti-inflammatory assay}

The chick carrageenan-induced foot edema model described by Roach and Sufka (2003) was used to evaluate the anti-inflammatory activity of $R$. indica extract and isolates with slight modifications (Boakye-Gyasi et al., 2008). The extract was dissolved in $0.9 \% \mathrm{NaCl}$ (normal saline), whereas the isolates were suspended in tragacanth mucilage $(1 \%)$ for oral administration. The extract was administered at 30,100, and $300(\mathrm{mg} / \mathrm{kg}$ body weight), whereas the isolates and diclofenac were given 10, 30, and $100 \mathrm{mg} / \mathrm{kg}$ body weight, orally, an hour before carrageenan injection $(100 \mu \mathrm{l}$ of $1 \%)$ subplantar into the right footpad. The ipsilateral foot thickness was measured using digital Vernier calipers pre- and post-carrageenan treatment at hourly intervals up to 5 hours. The control chicks received only the vehicle $(1 \%$ tragacanth mucilage) as treatment.

\section{Fractionation and isolation of compounds R1 and R12}

Gravity-fed column chromatography (CC) was used, employing silica gel (70-230 mesh, AppliChem, Darmstadt, Germany) as stationary phase material. Aluminum backed silica gel plates GF254 (0.25 mm thickness) were used for the analytical thin-layer chromatography (TLC).

An amount of silica gel 70-230 mesh ASTM (American society for testing materials) was packed dry into a column (90 $\times 5 \mathrm{~cm})$. The dried hydroethanolic stem bark extract $(30 \mathrm{~g})$ was reconstituted in methanol and adsorbed into a few grams of silica gel and dried in an oven at $60^{\circ} \mathrm{C}$. It was packed on top of the column and covered with cotton wool. Elution of the column was carried out using gradient mixtures of methanol, ethyl acetate, and petroleum ether (beginning with $100 \%$ pet-ether to $100 \%$ methanol) to afford five bulked fractions (F1-F5) based on their TLC profiles. About $4 \mathrm{~g}$ of bulked fraction R2 was loaded onto a glass column $(45 \times 2 \mathrm{~cm})$ and eluted using a gradient of petroleum ether and ethyl acetate to afford three bulked fractions (F1a, F1b, and F1c). Subfraction F1b was washed severally with pet-ether to afford a white crystalline compound (800 mg) labelled as compound R1.

About $3.89 \mathrm{~g}$ of fraction F4 was subjected to successive chromatographic separations on silica gel, employing gradient mixtures of pet-ether, ethyl acetate, and methanol. The fractions eluted with $100 \%$ ethyl acetate to methanol/ethyl acetate 1:4 were bulked together to afford a subfraction weighing $1.5 \mathrm{~g}$. Repeated $\mathrm{CC}$ of this fraction on silica gel, eluting isocratically with ethyl acetate/methanol 19:1, yielded compound R12 (650 mg) as an amorphous off-white solid.

\section{Experimental}

Compounds R1 and R12 were dissolved completely in deuterated chloroform $\left(\mathrm{CDCl}_{3}\right)$ and methanol $\left(\mathrm{CD}_{3} \mathrm{OD}\right)$, respectively. Bruker Avance $(500 \mathrm{MHz})$ machine was used to record the one- and two-dimensional Nuclear Magenetic Resonance (NMR) experiments at $25^{\circ} \mathrm{C}$. The internal standard used was tetramethylsilane, coupling constants $(\mathrm{J})$ were measured in Hertz $(\mathrm{Hz})$, and the chemical shifts $(\delta)$ were presented in parts per million (ppm). Fourier-transform infrared spectra (FT-IR) were obtained on a Bruker spectrophotometer.

\section{Statistical analysis}

All values were expressed as the mean \pm standard error mean (SEM, $n=5$ ). In the carrageenan-induced inflammation, raw values were calculated as the percentage increase in foot volume using the following equation:

$$
\% \text { increase in foot volume }=\left\|1-\left[\frac{F_{T}}{F_{B}}\right] \times 100\right\|
$$

where FT denotes post-carrageenan treatment foot volume of the chicks and FB denotes pre-carrageenan treatment foot volume of the chicks. The time-course curves were subjected to a two-way analysis of variance (ANOVA), followed by Dunnett's post hoc test. One-way ANOVA, followed by Dunnett's post hoc test, was used to analyze the anti-inflammatory activity for the treatment group, calculated as the area under the curve (AUC). 


\section{RESULTS}

\section{Structural elucidation of compounds}

\section{Elucidation of R1 as $\beta$-sitosterol}

The ${ }^{1} \mathrm{H}$ NMR spectrum of $\mathbf{R}-\mathbf{1}\left(\mathrm{CDCl}_{3}, 500 \mathrm{MHz}\right)$ (Table 1) revealed the presence of angular methyl singlets at $\delta_{\mathrm{H}}$ $0.68(\mathrm{H}-18)$ and $\delta_{\mathrm{H}} 1.00(\mathrm{H}-19)$ and an oxymethine multiplet at $\delta_{\mathrm{H}} 3.52(\mathrm{H}-3)$ which are consistent with a stigmastane steroidal nucleus (Fig. 1a) (Hua et al., 2012). Also indicated in the spectrum were signals for a trisubstituted olefinic proton signal at $\delta_{\mathrm{H}} 5.35$ (H-6) and upfield chemical shifts for a secondary methyl group $\left(\mathrm{H}-21, \delta_{\mathrm{H}} 0.95, d\right)$ and the terminal quaternary methyl group (H-29, $\delta_{\mathrm{H}} 0.82$, overlapping $t$ ) of the side chain. The isopropyl group in the side chain of the steroidal nucleus was indicated by signals at $\delta_{\mathrm{H}} 0.84(\mathrm{H}-26, d), \delta_{\mathrm{H}} 0.86(\mathrm{H}-27, d)$, and $\delta_{\mathrm{H}} 1.54(\mathrm{H}-25, m)$.

The ${ }^{13} \mathrm{C}$ NMR spectrum (Table 1 ) showed 29 carbons that included six methyls, 11 methylenes, nine methines (including an oxymethine), and three quaternary carbon atoms which were confirmed by the distortionless enhancement by polarization transfer (DEPT-135) spectra. The identifiable signals at $\delta_{\mathrm{C}} 140.8$ and

Table 1. ${ }^{1} \mathrm{H}$ and ${ }^{13} \mathrm{C}$ NMR data of RF-1 and $\beta$-sitosterol in deuterated chloroform.

\begin{tabular}{|c|c|c|c|c|}
\hline \multirow{2}{*}{ Position } & \multicolumn{2}{|r|}{ RF-1 } & \multicolumn{2}{|c|}{$\beta$-sitosterol ${ }^{a}$} \\
\hline & $\delta \mathrm{C}$ & $\delta \mathrm{H}(\mathrm{mult}, \mathrm{J}$ in $\mathrm{Hz})$ & $\delta \mathbf{C}$ & $\delta \mathrm{H}$ (mult, J in $\mathrm{Hz}$ ) \\
\hline 1 & $39.3\left(\mathrm{CH}_{2}\right)$ & $0.99,1.43$ & $37.9\left(\mathrm{CH}_{2}\right)$ & $0.99,1.73$ \\
\hline 2 & $32.6\left(\mathrm{CH}_{2}\right)$ & $1.58,1.26$ & $32.1\left(\mathrm{CH}_{2}\right)$ & $2.17,1.76$ \\
\hline 3 & $78.6(\mathrm{CH})$ & $3.52, m$ & $72.1(\mathrm{CH})$ & $3.60, m$ \\
\hline 4 & $42.3\left(\mathrm{CH}_{2}\right)$ & $2.26,1,98$ & $42.0\left(\mathrm{CH}_{2}\right)$ & $2.76,2.50$ \\
\hline 5 & $140.8(\mathrm{C})$ & - & $141.2(\mathrm{C})$ & - \\
\hline 6 & $121.7(\mathrm{CH})$ & $5.35, d$ & $121.0(\mathrm{CH})$ & 5.41 \\
\hline 7 & $31.9\left(\mathrm{CH}_{2}\right)$ & $1.55,1.90$ & $32.6\left(\mathrm{CH}_{2}\right)$ & $1.55,1.90$ \\
\hline 8 & $31.9(\mathrm{CH})$ & 1.38 & $32.0(\mathrm{CH})$ & 1.38 \\
\hline 9 & $51.4(\mathrm{C})$ & 1.51 & $50.0(\mathrm{C})$ & 0.91 \\
\hline 10 & $36.5(\mathrm{C})$ & - & $37.4(\mathrm{C})$ & - \\
\hline 11 & $23.7\left(\mathrm{CH}_{2}\right)$ & $1.44,1.45$ & $21.8\left(\mathrm{CH}_{2}\right)$ & $1.45,1.55$ \\
\hline 12 & $43.0\left(\mathrm{CH}_{2}\right)$ & $1.52,1.18$ & $37.2\left(\mathrm{CH}_{2}\right)$ & $1.98,1.04$ \\
\hline 13 & $46.6(\mathrm{C})$ & - & $44.4(\mathrm{C})$ & - \\
\hline 14 & $57.5(\mathrm{CH})$ & 0.90 & $56.8(\mathrm{CH})$ & 0.88 \\
\hline 15 & $26.7\left(\mathrm{CH}_{2}\right)$ & $1.04,1.57$ & $25.0\left(\mathrm{CH}_{2}\right)$ & $1.04,1.55$ \\
\hline 16 & $29.8\left(\mathrm{CH}_{2}\right)$ & $1.85,1.25$ & $29.0\left(\mathrm{CH}_{2}\right)$ & $1.85,1.25$ \\
\hline 17 & $56.8(\mathrm{CH})$ & 1.20 & $58.3(\mathrm{CH})$ & 1.11 \\
\hline 18 & $12.2\left(\mathrm{CH}_{3}\right)$ & $0.68, s$ & $12.4\left(\mathrm{CH}_{3}\right)$ & 0.78 \\
\hline 19 & $19.3\left(\mathrm{CH}_{3}\right)$ & $1.00, s$ & $19.7\left(\mathrm{CH}_{3}\right)$ & 1.08 \\
\hline 20 & $37.3(\mathrm{CH})$ & 1.40 & $36.4(\mathrm{CH})$ & 1.39 \\
\hline 21 & $19.2\left(\mathrm{CH}_{3}\right)$ & $0.95, d$ & $19.5\left(\mathrm{CH}_{3}\right)$ & $0.99, d$ \\
\hline 22 & $36.8\left(\mathrm{CH}_{2}\right)$ & 1.20 & $34.1\left(\mathrm{CH}_{2}\right)$ & 1.19 \\
\hline 23 & $28.9\left(\mathrm{CH}_{2}\right)$ & 1.25 & $26.8\left(\mathrm{CH}_{2}\right)$ & 1.25 \\
\hline 24 & $49.5(\mathrm{CH})$ & 0.94 & $47.1(\mathrm{CH})$ & 1.01 \\
\hline 25 & $30.2(\mathrm{CH})$ & $1.54, m$ & $31.9(\mathrm{CH})$ & 1.69 \\
\hline 26 & $20.1\left(\mathrm{CH}_{3}\right)$ & $0.84, d$ & $19.9\left(\mathrm{CH}_{3}\right)$ & 0.88 \\
\hline 27 & $21.7\left(\mathrm{CH}_{3}\right)$ & $0.86, d$ & $20.5\left(\mathrm{CH}_{3}\right)$ & 0.89 \\
\hline 28 & $24.9\left(\mathrm{CH}_{2}\right)$ & 1.30 & $23.8\left(\mathrm{CH}_{2}\right)$ & 1.30 \\
\hline 29 & $12.3\left(\mathrm{CH}_{3}\right)$ & $0.82, t$ & $12.8\left(\mathrm{CH}_{3}\right)$ & 0.94 \\
\hline
\end{tabular}

aNMR data obtained from Zhao et al. (2016).
$\delta_{\mathrm{C}} 121.7$, which are characteristic of a double bond, were assigned as C-5 and C-6, respectively. Heteronuclear multiple bond correlations (HMBC) between the olefinic proton $(\mathrm{H}-6)$ and carbons $\mathrm{C}-4\left(\delta_{\mathrm{C}}\right.$ 42.3), $\mathrm{C}-7\left(\delta_{\mathrm{C}} 31.9\right), \mathrm{C}-8\left(\delta_{\mathrm{C}} 31.9\right)$, and $\mathrm{C}-10\left(\delta_{\mathrm{C}} 36.5\right)$ and between $\mathrm{H}-3$ and $\mathrm{H}-9\left(\delta_{\mathrm{H}} 1.51\right)$ and $\mathrm{C}-5$ confirmed the double bond at C-5/C-6 (Supplementary Material). The hydroxyl group at C-3 heteronuclear single quantum correlations (HSQC) with the oxymethine carbon at $\delta_{\mathrm{C}}$ 71.7. Examination of the NMR data of $\mathbf{R}-\mathbf{1}$ showed that it was compared favorably with reported literature for $\beta$-sitosterol (Pierre and Moses, 2015; Zhao et al., 2016).

Electron spray ionisation mass spectrometry (ESI-MS) data showed the molecular formula of R-1 to be $\mathrm{C}_{29} \mathrm{H}_{50} \mathrm{O}$. It gave a positive test for steroids and absorption bands for a hydroxyl group and a single double $\mathrm{C}=\mathrm{C}$ were shown in FT-IR spectra, further confirming $\mathbf{R}-\mathbf{1}$ as $\beta$-sitosterol.

\section{Elucidation of $R-12$ as arjunolic acid}

The FT-IR spectra of compound R-12, a white amorphous powder, displayed absorption bands for hydroxyl and olefinic groups at $v_{\max }$ of 3,591 and $1,685 \mathrm{~cm}^{-1}$, respectively. The molecular formula was determined as $\mathrm{C}_{30} \mathrm{H}_{48} \mathrm{O}_{5}$ from a molecular ion peak at $\mathrm{m} / z 511.3438[\mathrm{M}+\mathrm{Na}]^{+}$in the high resolution electron spray ionisation mass spectrometry (HR-ESIMS), suggesting that R-12 is a triterpenoid.

The ${ }^{1} \mathrm{H}$ NMR spectrum of R-12 (500 MHz, CD OD) (Table 2) indicated the presence of six aliphatic methyl singlets at $\delta_{\mathrm{H}} 0.72(\mathrm{H}-24), 0.84(\mathrm{H}-25), 0.93(\mathrm{H}-29), 0.96(\mathrm{H}-30), 1.05(\mathrm{H}-$ $26)$, and $1.20(\mathrm{H}-27)$ and an olefinic proton at $\delta_{\mathrm{H}} 5.27(\mathrm{H}-12$, br, $s)$. The spectrum also showed resonances for two protons at $\delta_{\mathrm{H}}$ $3.52(1 \mathrm{H}, d)$ and $\delta_{\mathrm{H}} \delta 3.56(1 \mathrm{H}, m)$ assigned to methine protons on oxygenated carbons. The ${ }^{13} \mathrm{C}$ NMR and DEPT 135 data (Table 2) revealed 30 carbon signals that included six methyls $\left(\delta_{\mathrm{C}} 12.4[\mathrm{C}\right.$ 24], 16.2 [C-25], 16.4 [C-26], 22.6 [C-30], 25.1 [C-27], and 32.2 [C-29]) and a carboxyl at $\delta_{C} 180.4(\mathrm{C}-28)$. The presence of a double bond in the ${ }^{1} \mathrm{H}-\mathrm{NMR}$ spectrum was corroborated by resonances at $\delta_{\mathrm{C}} 122.1$ and $\delta_{\mathrm{C}} 144.0$ in the ${ }^{13} \mathrm{C}$ NMR spectrum, assigned to $\mathrm{C}-12$ and $\mathrm{C}-13$, respectively. Furthermore, the spectrum also showed signals for three oxygen-bearing carbons (two oxymethines; $\delta_{\mathrm{C}}$ $68.3[\mathrm{C}-2]$ and $\delta_{\mathrm{C}} 77.0[\mathrm{C}-3]$; and an oxymethylene, $\delta_{\mathrm{C}} 65.2[\mathrm{C}-$ 23]). These data indicated that $\mathbf{R}-\mathbf{1 2}$ possessed an olean-12-en28-oic acid skeleton with three hydroxyl groups in its structure (Fig. 2) (Ahmad, 1994; Xu et al., 2018).

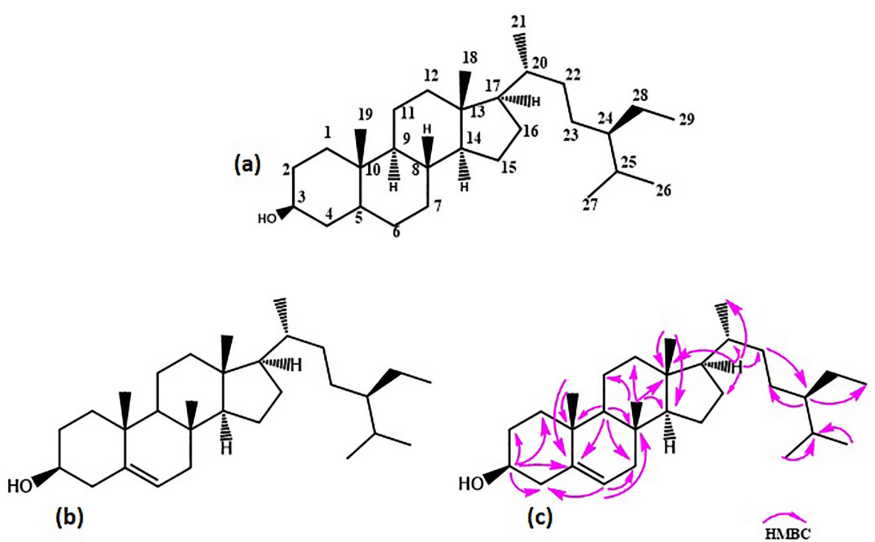

Figure 1. Stigmastane steroidal nucleus (a) and HMBC correlations (c) of compound R-1 (b). 
Table 2. ${ }^{1} \mathrm{H}$ and ${ }^{13} \mathrm{C}$ NMR data of $\mathbf{R F}-12$ and arjunolic acid

\begin{tabular}{|c|c|c|c|c|}
\hline \multirow{2}{*}{ Position } & \multicolumn{2}{|r|}{ RF-12 } & \multicolumn{2}{|c|}{ Arjunolic acid ${ }^{a}$} \\
\hline & $\delta \mathrm{C}$ & $\delta \mathrm{H}($ mult, $\mathrm{J}$ in $\mathrm{Hz})$ & $\delta \mathrm{C}$ & $\delta \mathrm{H}($ mult, $\mathrm{J}$ in $\mathrm{Hz})$ \\
\hline 1 & $46.9\left(\mathrm{CH}_{2}\right)$ & $1.93,1.95$ & 47.1 & $1.32,1.21$ \\
\hline 2 & $68.3(\mathrm{CH})$ & $3.56, m$ & 68.9 & $3.52, d d d$ \\
\hline 3 & $77.0(\mathrm{CH})$ & $3.52, d$ & 78.7 & $3.36, d$ \\
\hline 4 & $44.2(\mathrm{C})$ & - & 43.5 & - \\
\hline 5 & $48.1(\mathrm{CH})$ & $1.32, s$ & 48.4 & $1.15, s$ \\
\hline 6 & $18.6\left(\mathrm{CH}_{2}\right)$ & $1.52,1.27$ & 18.6 & $1.28,1.17$ \\
\hline 7 & $33.4\left(\mathrm{CH}_{2}\right)$ & $1.56,1.31$ & 33.1 & $1.38,1.22$ \\
\hline 8 & $39.8(\mathrm{C})$ & - & 40.1 & - \\
\hline 9 & $48.2(\mathrm{CH})$ & $1.40, s$ & 48.5 & $1.26, s$ \\
\hline 10 & $38.4(\mathrm{C})$ & - & 38.5 & - \\
\hline 11 & $23.8\left(\mathrm{CH}_{2}\right)$ & $2.01,1.74$ & 23.8 & $1.91,1.53$ \\
\hline 12 & $\begin{array}{l}122.1 \\
(\mathrm{CH})\end{array}$ & $5.27, \mathrm{br}, s$ & 123.5 & $5.17, \mathrm{br}, s$ \\
\hline 13 & $144.0(\mathrm{C})$ & - & 144.1 & - \\
\hline 14 & $41.8(\mathrm{C})$ & - & 42.4 & - \\
\hline 15 & $28.1\left(\mathrm{CH}_{2}\right)$ & $1.36,1.10$ & 28.3 & $1.24,1.13$ \\
\hline 16 & $23.9\left(\mathrm{CH}_{2}\right)$ & $1.61,1.31$ & 23.9 & $1.60,1.36$ \\
\hline 17 & 46.7 (C) & - & 47.0 & - \\
\hline 18 & $43.2(\mathrm{CH})$ & $2.87, d d$ & 43.5 & $2.62, d d$ \\
\hline 19 & $46.5\left(\mathrm{CH}_{2}\right)$ & $1.49,1.24$ & 46.3 & $1.52,1.22$ \\
\hline 20 & $31.1(\mathrm{CH})$ & - & 30.7 & - \\
\hline 21 & $34.3\left(\mathrm{CH}_{2}\right)$ & $1.56,1.31$ & 34.2 & $1.28,1.17$ \\
\hline 22 & $33.1\left(\mathrm{CH}_{2}\right)$ & $2.01,1.76$ & 33.0 & $1.28,1.17$ \\
\hline 23 & $65.2\left(\mathrm{CH}_{2}\right)$ & $3.31, d ; 3.37, d$ & 67.2 & $3.06, d ; 3.18, d$ \\
\hline 24 & $12.4\left(\mathrm{CH}_{3}\right)$ & $0.72, s$ & 14.0 & $0.53, s$ \\
\hline 25 & $16.2\left(\mathrm{CH}_{3}\right)$ & $0.84, s$ & 17.6 & $0.71, s$ \\
\hline 26 & $16.4\left(\mathrm{CH}_{3}\right)$ & $1.05, s$ & 17.2 & $0.92, s$ \\
\hline 27 & $25.1\left(\mathrm{CH}_{3}\right)$ & $1.20, s$ & 26.1 & $1.11, s$ \\
\hline 28 & $180.4(\mathrm{C})$ & - & 178.6 & - \\
\hline 29 & $32.2\left(\mathrm{CH}_{3}\right)$ & $0.93, s$ & 29.1 & $0.86, s$ \\
\hline 30 & $22.6\left(\mathrm{CH}_{3}\right)$ & $0.96, s$ & 23.7 & $0.86, s$ \\
\hline
\end{tabular}

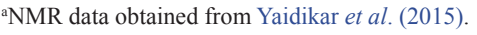

The position of the carboxylic acid group at $\mathrm{C}-17$ was confirmed based on $\mathrm{HMBC}$ correlations between the signal at $\delta_{\mathrm{H}}$ $2.87(\mathrm{H}-18)$ with $\delta_{\mathrm{C}} 46.7(\mathrm{C}-17)$ and the carboxyl carbon signal $\delta_{\mathrm{C}}$ 180.4 (C-28). HMBC correlations between $\mathrm{H}-18\left(\delta_{\mathrm{H}} 2.87\right)$ and $\delta_{\mathrm{C}}$ $144.0(\mathrm{C}-13)$ and long-range correlations from $\mathrm{H}-18\left(\delta_{\mathrm{H}} 2.87\right)$ and $\mathrm{H}-27\left(\delta_{\mathrm{H}} 1.20\right)$ to $\delta_{\mathrm{C}} 122.1(\mathrm{C}-12)$ together with ${ }^{1} \mathrm{H}-{ }^{1} \mathrm{H}$ correlation spectroscopy (COSY) correlations between $\delta_{\mathrm{H}} 2.01 / 1.74(\mathrm{H}-11)$ and $\delta_{\mathrm{H}} 5.27(\mathrm{H}-12)$ confirmed the olefinic group at $\mathrm{C}-12$ and $\mathrm{C}-13$. Hydroxyl groups at C-2 and C-3 of the oleanane structure were evident from both the resonances and pattern of chemical shifts of the protons attributed to $\mathrm{H}-2\left(\delta_{\mathrm{H}} 3.56, m\right)$ and $\mathrm{H}-3\left(\delta_{\mathrm{H}} 3.52, d\right)$, which gave HSQC cross peaks with the oxymethine carbons at $\delta_{\mathrm{C}}$ $68.2(\mathrm{C}-2)$ and $\delta_{\mathrm{C}} 77.0(\mathrm{C}-3)$, respectively. HMBC correlations from the singlet signal at $\delta_{\mathrm{H}} 0.72(\mathrm{H}-24)$ and the oxymethylene protons at $\mathrm{H}-23\left(\delta_{\mathrm{H}} 3.31, d / 3.37, d\right)$ to $\delta_{\mathrm{C}} 77.0(\mathrm{C}-3) ; \mathrm{H}-1\left(\delta_{\mathrm{H}} 1.93 / 1.95\right)$ to $\delta_{\mathrm{C}}$ $68.2(\mathrm{C}-2)$ and $\delta_{\mathrm{C}} 77.0(\mathrm{C}-3)$ together with ${ }^{1} \mathrm{H}-{ }^{1} \mathrm{H}$ COSY correlations between $\mathrm{H}-1$ and $\mathrm{H}-2$ confirmed the hydroxyl groups at C-2 and C-3 and established the doublet signal at C-3. The large coupling constant

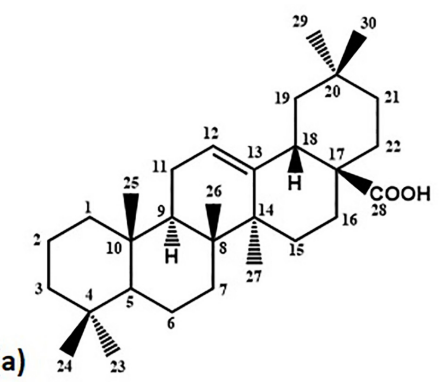

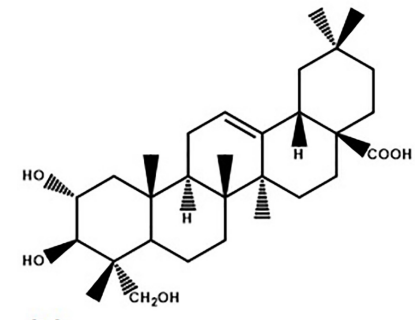

(b)

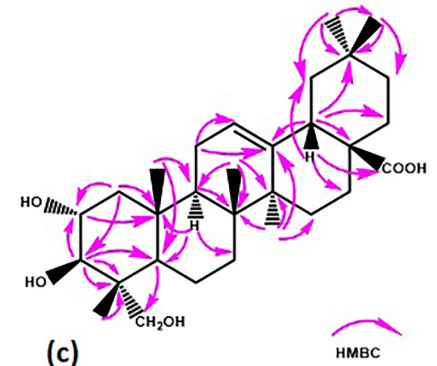

(c)
Figure 2. An oleanane-type triterpenoid skeleton (a) and HMBC correlations (c) of compound R-12(c).

between $\mathrm{H}-2$ and $\mathrm{H}-3(11 \mathrm{~Hz})$ indicated their axial orientations and pointed to the equatorial arrangements of the hydroxyl groups at C-2 and C-3 ( $2 \alpha, 3 \beta$ oriented).

Furthermore, the ${ }^{1} \mathrm{H}$ NMR spectrum revealed two oneproton doublets $\left(\delta_{\mathrm{H}} 3.29\right.$ and $\left.3.38[\mathrm{~J}=11 \mathrm{~Hz}]\right)$ on the ${ }^{1} \mathrm{H}$ NMR which showed HSQC correlations with the downfield carbon signal at $\delta_{\mathrm{C}}$ 65.2. This in turn showed HMBC cross peaks with the oxymethine proton at $\delta_{\mathrm{H}} 3.52(\mathrm{H}-3)$ and the singlet at $\delta_{\mathrm{H}} 0.72$ (attributed to the $\mathrm{C}-24$ methyl protons). This information together with $\mathrm{HMBC}$ correlations between the oxymethylene protons and the downfield quaternary carbon resonance at $\delta_{\mathrm{C}} 44.2$ assigned as $\mathrm{C}-4$ and the oxymethine carbon, $\delta_{\mathrm{C}} 77.0$ (C-3), strongly suggested that the third hydroxyl substituent was at $\mathrm{C}-23\left(\delta_{\mathrm{C}} 65.2\right)$.

Therefore, $\mathbf{R}-\mathbf{1 2}$ was elucidated as $2 \alpha, 3 \beta$, 23-trihydroxyolean-12-en-28-oic acid. This structure was confirmed through HMBC correlations that included long-range correlations from the oxymethine proton $\mathrm{H}-2\left(\delta_{\mathrm{H}} 3.56\right)$ to $\mathrm{C}-10\left(\delta_{\mathrm{C}}\right.$ $38.4)$; $\mathrm{H}-3\left(\delta_{\mathrm{H}} 3.52\right)$ and $\mathrm{H}-25\left(\delta_{\mathrm{H}} 0.84\right)$ to $\mathrm{C}-5\left(\delta_{\mathrm{C}} 48.1\right) ; \mathrm{H}-18\left(\delta_{\mathrm{H}}\right.$ $2.88)$ to $\mathrm{C}-20\left(\delta_{\mathrm{C}} 30.9\right)$ and $\mathrm{C}-28\left(\delta_{\mathrm{C}} 181.4\right) ; \mathrm{H}-9\left(\delta_{\mathrm{H}} 1.40\right)$ to $\mathrm{C}-12$ $\left(\delta_{\mathrm{C}} 122.1\right)$; and H-27 $\left(\delta_{\mathrm{H}} 1.17\right)$ to $\mathrm{C}-13\left(\delta_{\mathrm{C}} 144.0\right)$.

The spectral data of R-12 correlated well with reported literature on arjunolic acid isolated from the stem barks of Terminalia arjuna (Combretaceae) (Miriyala et al., 2015; Yaidikar and Thakur, 2015); thus, R-12 was identified as arjunolic acid. Therefore, we report for the first time, the isolation of arjunolic acid from the plant $R$. indica. All spectroscopic data of R-1 and R-12 are available as Supplementary Material.

\section{Anti-inflammatory activity of extracts and compounds}

$R$. indica extract and reference drug, diclofenac, exhibited a dose-dependent anti-inflammatory effect (Fig. 3). The stem bark extract, RE (at $100 \mathrm{mg} / \mathrm{kg}$ body weight), in this preemptive protocol, caused the mean edema attained at 2 hours to be reduced significantly $(p<0.5)$ by $28.33 \% \pm 6.63 \%$ 
a.

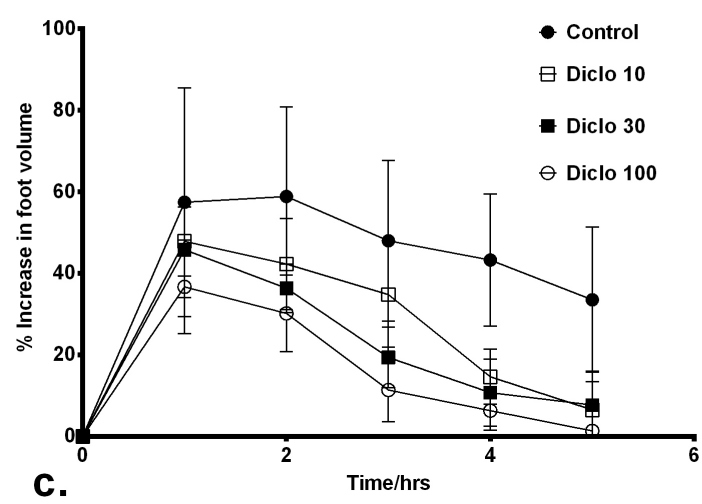

C.

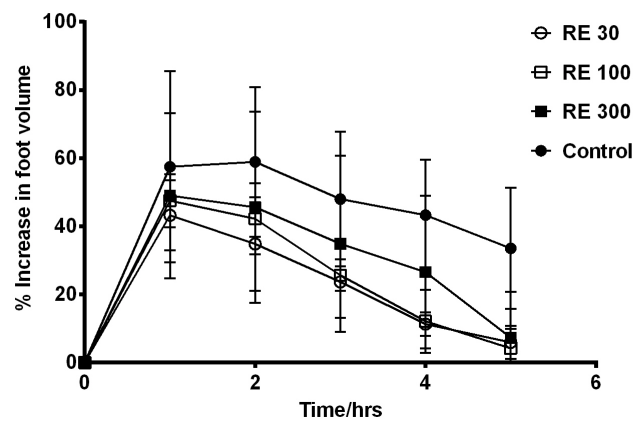

b.

d.
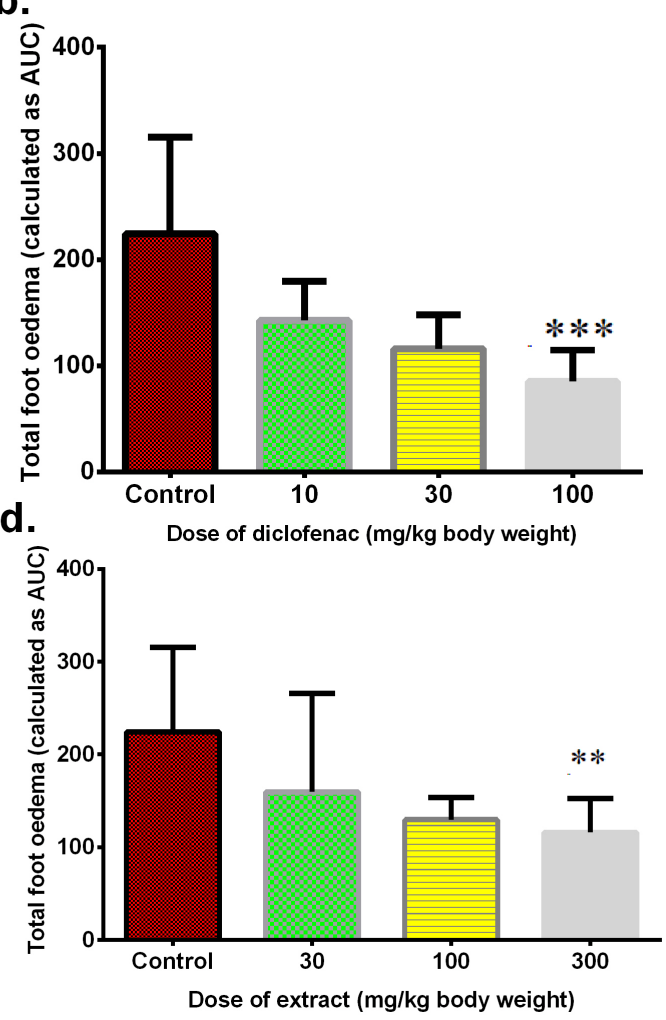

Figure 3. Effect of oral administration of RE (30-300 mg/kg) and diclofenac (10-100 mg/kg) on time-course curves (a, c) and the total edema response (b, d) expressed as AUC. Values are mean $\pm \operatorname{SEM}(n=5) .{ }^{*} p<0.05 ; * * p<0.01 ; * * p<0.001$ compared to the vehicle-treated group (one-way ANOVA, followed by Dunnett's $p o s t$ hoc test).

of the inflamed control response (Fig. 3c). Diclofenac (at 100 $\mathrm{mg} / \mathrm{kg}$ body weight), within the same period, inhibited edema formation by $48.74 \% \pm 8.63 \%$ (Fig. 3a). Similarly, the isolated compounds sitosterol (R1) and arjunolic acid (R12) showed dose-dependent inhibition of edema induced in the 7-day-old chick (Fig. 4). The rank order of activity, as measured by the $\mathrm{ED}_{50}$, was diclofenac $>$ crude extract $(\mathrm{Re})>$ arjunolic acid $(\mathrm{R} 12)$ $>$ sitosterol (R1) (Table 3).

\section{Antioxidant activities of extracts and compounds}

The extract, isolates, and ascorbic acid showed considerable DPPH radical scavenging activities. Ascorbic acid showed a higher free radical scavenging effect than crude extract (RE) (Table 3). The crude extract was also a more potent scavenger of the DPPH radical than arjunolic acid (R12) and sitosterol (R1), respectively (Table 3). Similarly, in the total antioxidant capacity assay, measured as the AAE, the hydroethanolic stem bark extract was about two and 16 times more powerful an antioxidant than sitosterol and arjunolic acid, respectively (Table 3 ).

\section{Antimicrobial activities of extracts and compounds}

The MIC of Reissantia extract and its isolated compounds sitosterol and arjunolic acid against the Gram-negative and Grampositive bacteria were within the range of $2.5-20 \mathrm{mg} / \mathrm{ml}$ (Table 4). The crude extract was more active than the isolated compounds.
Sitosterol was not active at the highest tested concentration (20 $\mathrm{mg} / \mathrm{ml}$ ).

\section{DISCUSSION}

Inflammation is associated with a number of triggers including microbial infections, environmental exposures (including asbestos exposure and smoke inhalation), and immune diseases. There is growing evidence of the implication of inflammation in almost all diseases (Hunter, 2012). Inflammation studies have, therefore, gained wide attention in the understanding of a number of human diseases. Thus, anti-inflammatory agents/compounds could be repurposed for other diseases and open a vast range of possibilities in their medical applications (Arulselvan et al., 2016).

The present research, therefore, explored the antiinflammatory, antioxidant, and antimicrobial activities of $R$. indica, an acclaimed folklore medicine for inflammatory diseases and infection control. In the anti-inflammatory study, acute inflammation was induced by injecting kappa-carrageenan in the right footpad of the chicks. It is used as an edemogenic agent because inflammation induced with carrageenan is easily reproducible. Also, carrageenan is able to mimic the acute inflammatory phase by provoking the release of proinflammatory markers like histamine, serotonin, bradykinin, and prostaglandin involved in acute inflammation (Obiri and Osafo, 2013). Reissantia indica and its compounds showed considerable anti- 
a.

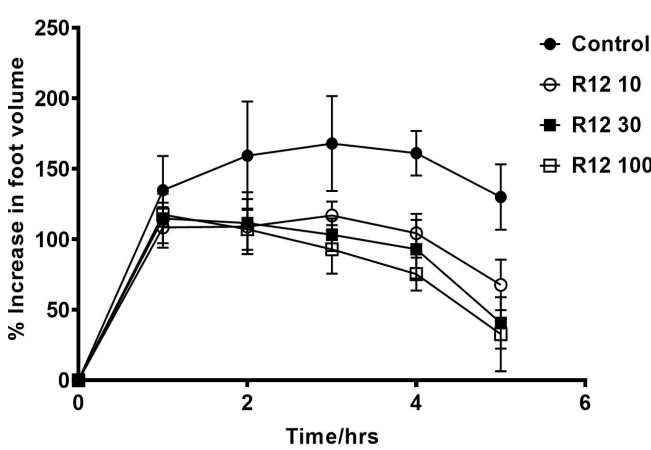

C.

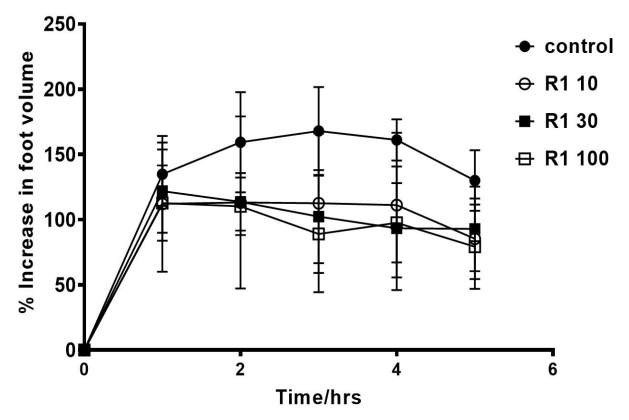

b.

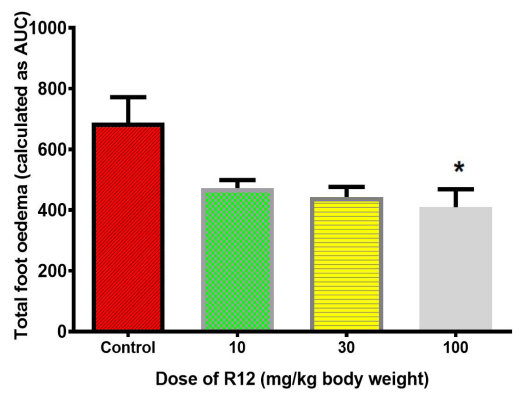

d.

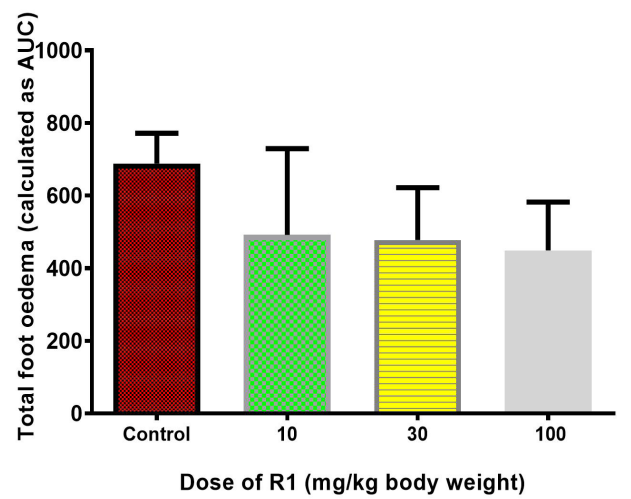

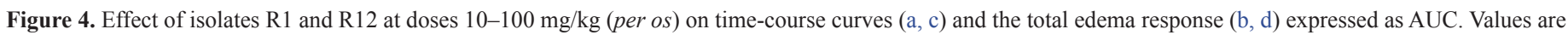
mean $\pm \operatorname{SEM}(n=5) .{ }^{*} p<0.05$ compared to the vehicle-treated group (one-way ANOVA, followed by Dunnett's post hoc test).

Table 3. Antioxidant and anti-inflammatory activities of extracts and isolates from $R$. indica stem bark.

\begin{tabular}{|c|c|c|c|}
\hline Extract/compound & $\mathrm{DPPH} \mathrm{IC}_{50}(\mu \mathrm{g} / \mathrm{mL}) \pm \mathrm{SD}$ & $\begin{array}{c}\text { Total antioxidant capacity } \\
\text { (TAC) AAE (mg/g of material) }\end{array}$ & $\mathrm{ED}_{50}(\mathrm{mg} / \mathrm{kg}$ body weight $)$ \\
\hline RE & $44 \pm \mathbf{3 . 8 5}$ & $300 \pm 4.24$ & $33.02 \pm 3.66$ \\
\hline $\mathrm{R} 1$ & $67.34 \pm 3.42$ & $22 \pm 2.21$ & $116.4 \pm 2.47$ \\
\hline $\mathrm{R} 12$ & $65.21 \pm \mathbf{2 . 4 9}$ & $124 \pm 2.33$ & $34.77 \pm 4.61$ \\
\hline Ascorbic acid & $25.25 \pm \mathbf{6 . 5 9}$ & & Not tested \\
\hline Diclofenac & Not tested & Not tested & $20.49 \pm \mathbf{2 . 2 6}$ \\
\hline
\end{tabular}

$\mathrm{AAE}=$ ascorbic acid equivalent; $\mathrm{RE}=$ hydroethanolic extract of $R$. indica $\mathrm{R} 1$ and $\mathrm{R} 12$ = compounds sitosterol and arjunolic acid, respectively; TAC: total antioxidant capacity.

Table 4. MIC of R. indica extract, isolated compounds, and reference drugs.

\begin{tabular}{|c|c|c|c|c|c|}
\hline Organisms & Extract & $\mathrm{R} 1 \mathrm{mg} / \mathrm{ml}$ & R12 & Clotrimazole $1 \%$ & Ciprofloxacin $\mu \mathrm{g} / \mathrm{ml}$ \\
\hline K. pneumonia & 5 & $>20$ & 10 & NT & 62.5 \\
\hline S. aureus & 5 & $>20$ & 10 & NT & 250 \\
\hline S. typhi & 5 & $>20$ & 5 & NT & 250 \\
\hline E. coli & 2.5 & $>20$ & 2.5 & NT & 250 \\
\hline E. faecalis & 2.5 & $>20$ & 5 & NT & 125 \\
\hline P. aeruginosa & 5 & $>20$ & 5 & NT & 250 \\
\hline S. pneumonia & 2.5 & $>20$ & 5 & NT & 125 \\
\hline C. albicans & 5 & $>20$ & 10 & $<1 \%$ & NT \\
\hline
\end{tabular}

$\mathrm{NT}=$ not tested; $\mathrm{R} 1=$ sitosterol; $\mathrm{R} 12=$ arjunolic acid. 
inflammatory activities. The total footpad swellings induced over the 5-hour period was significantly $(p<0.05)$ inhibited by $48.26 \% \pm 2.3 \%$ and $42.21 \% \pm 4.13 \%$ at the $300 \mathrm{mg} / \mathrm{kg}$ and 100 $\mathrm{mg} / \mathrm{kg}$ body weight treatment groups, respectively, compared to the inflamed control response. Diclofenac, at doses of 100 and 30 $\mathrm{mg} / \mathrm{kg}$, inhibited edema formation by $62.05 \pm 3.20$ and $48.19 \% \pm$ $1.42 \%$, respectively (Fig. $3 \mathrm{a}$ ).

The anti-inflammatory activity of the extract, as measured by the $\mathrm{ED}_{50}$, was about four times higher than that of sitosterol but very much comparable to that of arjunolic acid (Table 3). Carrageenan-induced edema in murine models is biphasic (Vinegar et al., 1969). Phase one lasts 1-2 hours and is mainly enhanced by proinflammatory markers and increased synthesis of prostaglandins by the surroundings injured tissues. Also, phase 2 is maintained by the actions of prostaglandins and other leucocytes (Vasudevan et al., 2007). Although the exact mechanisms of action of extract and the isolates are not yet known, the probable anti-inflammatory activity exhibited by $R$. indica stem bark could be due to the attenuation of the production and release of inflammatory mediators involved in carrageenan-induced edema. This result suggests that $R$. indica and its isolates act in both the early and later phases of carrageenan-induced edema (Figs. 3 and 4). This validates its use in folklore medicine.

The stem bark extract of $R$. indica also showed considerable free radical scavenging activity (Table 3 ). The activity of the extract was higher than that of its bioactive compounds sitosterol and arjunolic acid. This is also reflected in the total antioxidant capacity assay. The activity was about 14 and two times more than these respective compounds (Table 3), suggestive of potential synergistic activity of the constituents. The antioxidant activity may lend support to the anti-inflammatory activity observed in this study because during the inflammatory process, there is enhanced production and release of reactive oxygen radicals, alongside other mediators, due to the presence of leukocytes and mast cells at the site of inflammation (Coussens et al., 2002; Hussain et al., 2003). The "oxidative-inflammatory" environment created may lead to oxidative stress, which has been shown to damage vital cellular structures, leading to a number of chronic diseases. Antioxidant molecules can remove excess free radicals and restore reactive oxygen species formation and endogenous antioxidant defense balance, thereby halting disease progression (Arulselvan et al., 2016). The extracts and compounds also showed considerable antimicrobial activities against a host of Gram-negative and Gram-positive organisms. The activities were, however, weak compared to ciprofloxacin and clotrimazole used as reference agents. Reissantia indica stem bark may owe its antimicrobial activity, in part, to arjunolic acid (Table 4) since the other isolated compound, sitosterol, was not active at the tested concentration $(20 \mathrm{mg} / \mathrm{ml})$.

The biological activities of the triterpenoids sitosterol and arjunolic acid, reported in this study, are in agreement with the reflections of a number of authors. For example, arjunolic acid has been found to maintain the levels of antioxidant enzymes, including glutathione peroxidase, glutathione reductase, glutathione-S-transferase, and catalase superoxide dismutase, thereby reducing oxidative stress (Nanda et al., 2017). Facundo et al. (2005) reported the anti-inflammatory, antinociceptive, and anticholinesterase activities of arjunolic acid from Combretum leprosum root. It is used as a cardiotonic in Ayurvedic medicine due to its ability to prevent myocardial necrosis, platelet aggregation, and blood pressure-lowering activities (Hemalatha et al., 2010). The cytoprotection exerted by arjunolic acid has been ascribed to its ability to reduce oxidative stress by enhancing the levels of antioxidants. Elsewhere, its antimicrobial activities are well documented (Masoko et al., 2008). Sitosterol is also on record to exhibit anti-inflammatory, antioxidant, antimicrobial, and antidiabetic properties (Gupta et al., 2011; Ododo et al., 2016; Paniagua-Pérez et al., 2016).

Reissantia indica, like other members of the Celastraceae, is known to accumulate mainly triterpenoids. The triterpenoids reissantenol oxide, sitosterol, canophyllol, pristimerin, and tingenone have been documented from the stem bark of the plant (Gamlath et al., 1989). However, to the best of our knowledge, this is the first record of the isolation of arjunolic acid from $R$. indica.

\section{CONCLUSION}

Reissantia indica hydroethanolic stem bark extract shows considerable anti-inflammatory, antioxidant, and antimicrobial properties as suggested by folklore medicine. The activities were due to its triterpenoids sitosterol and arjunolic acid. Arjunolic acid is reported for the first time in $R$. indica and contributed significantly to the observed biological activities of the plant.

\section{ACKNOWLEDGMENTS}

We are indebted to staff of the University of Dundee, Welcome Centre for Anti-Infectives Research, for generously running the NMR spectra. Technical staff of the Departments of Pharmacognosy, Pharmacology and Pharmaceutical Microbiology, are duly acknowledged for their invaluable support.

\section{AUTHOR CONTRIBUTIONS}

All authors made substantial contributions to conception and design, acquisition of data, or analysis and interpretation of data; took part in drafting the article or revising it critically for important intellectual content; agreed to submit to the current journal; gave final approval of the version to be published; and agree to be accountable for all aspects of the work. All the authors are eligible to be an author as per the international committee of medical journal editors (ICMJE) requirements/guidelines.

\section{FUNDING}

There is no funding to report.

\section{CONFLICTS OF INTEREST}

The authors report no financial or any other conflicts of interest in this work.

\section{ETHICAL APPROVALS}

Study protocol was approved by the Department of Pharmacology Ethics Committee, KNUST-Kumasi, Ghana.

\section{PUBLISHER'S NOTE}

This journal remains neutral with regard to jurisdictional claims in published institutional affiliation. 


\section{REFERENCES}

Ahmad VU. Handbook of natural products data. Volume 2: pentacyclic triterpenoids. Elsevier Science, Burlington, MA, 1994.

Angiolella L, Sacchetti G, Efferth T. Antimicrobial and antioxidant activities of natural compounds. Evid Based Complement Alternat Med, 2018; 158:91-105.

Arulselvan P, Fard MT, Tan WS, Gothai S, Fakurazi S, Norhaizan ME, Kumar SS. Role of antioxidants and natural products in inflammation. Oxid Med Cell Longev, 2016; 2016:5276130.

Boakye-Gyasi E, Woode E, Ainooson GK, Obiri DD, Ansah C, Duwejua M, Donkoh A. Anti-inflammatory and antipyretic effects of an ethanolic extract of Palisota hirsuta K. schum roots. African J Pharm Pharmacol, 2008; 2:191-9.

Cos P, Vlietinck AJ, Berghe VD, Maes L. Anti-infective potential of natural products: how to develop a stronger in vitro "proof-of-concept." J Ethnopharmacol, 2006; 106:290-302.

Coussens LM, Werb Z. Inflammation and cancer. Nature, 2002; 420(6917):860-7.

Cowan MM. Plant products as antimicrobial agents. Clin Microbiol Rev, 1999; 12(4):564-82.

Eaves-Pyles T, Allen CA, Taormina J, Swidsinski A, Tutt CB, Jezek GE, Islas-Islas M, Torres AG. Escherichia coli isolated from a Crohn's disease patient adheres, invades, and induces inflammatory responses in polarized intestinal epithelial cells. Int J Med Microbiol, 2008; 298(5-6):397-409.

Elkhair EA, Fadda H, Mohsen UA. Antibacterial activity and phytochemical analysis of some medicinal plants from Gaza Strip-Palestine. Journal of Al-Azar University-Gaza, 2010; 12:45-54.

Facundo VA, Rios KA, Medeiros CM, Militão JSLT, Miranda ALP, Epifanio RA, Carvalho MP, Andrade AT, Pinto AC, Rezende CM. Arjunolic acid in the ethanolic extract of Combretum leprosum root and its use as a potential multi-functional phytomedicine and drug for neurodegenerative disorders: anti-inflammatory and anticholinesterasic activities. J Braz Chem Soc, 2005; 16(6):1309-12.

Ferrero-Miliani L, Nielsen O, Andersen P, Girardin S. Chronic inflammation: importance of NOD2 and NALP3 in interleukin-1 $\beta$ generation. Clin Exp Immunol, 2007; 147:227-35.

Gamlath, CB, Gunatilaka, AAL, Subramaniam, S. Studies on terpenoids and steroids. Part 19.' Structures of three novel 19(10+9)aQeo8a,Sp,I Oar-Euphane Triterpenoids from Reissantia indica (Celastraceae). J Chem Soc Perkin 1, 1989; 2259-67.

Gayathri P, Sekar VD, Sudhakar K, Sangeetha M, Chamundeeswari D. Effect of ethanolic extract of Reissantia indica on the human breast cancer cell line (MCF-7). J Phytopharmacol, 2018; 7(1):10-2.

Govindappa M, Sadananda T, Channabasava R, Raghavendra VB. In vitro Anti-inflammatory, Lipoxygenase, Xanthine oxidase and acetycholinesterase inhibitory activity of Tecoma stans (L.) Juss. Ex Kunth. Int J Pharma Bio Sci, 2011; 2:275-85.

Guardia T, Rotelli AE, Juarez AO, Pelzer LE. Anti-inflammatory properties of plant flavonoids. Effects of rutin, quercetin and hesperidin on adjuvant arthritis in rat. Farmaco, 2001; 56(9):683-7.

Gupta R, Sharma AK, Dobhal MP, Sharma MC, Gupta RS. Antidiabetic and antioxidant potential of $\beta$-sitosterol in streptozotocininduced experimental hyperglycemia. J Diabetes, 2011; 3(1):29-37.

Hemalatha T, Pulavendran S, Balachandran C, Manohar BM, Puvanakrishnan R. Arjunolic acid: a novel phytomedicine with multifunctional therapeutic applications. Indian J Exp Biol, 2010; 48(3):238-47.

Hua L, Qi WY, Hussain SH, Gao K, Arfan M. Highly oxygenated stigmastane-type steroids from the aerial parts of Vernonia anthelmintica Willd. Steroids, 2012; 77(7):811-8.

Hunter P. The inflammation theory of disease. The growing realization that chronic inflammation is crucial in many diseases opens new avenues for treatment. EMBO Rep, 2012; 13(11):968-70.

Hussain SP, Hofseth LJ, Harris CC. Radical causes of cancer Nat Rev Cancer, 2003; 3(4):276-85.
Kidd BL, Urban LA. Mechanisms of inflammatory pain. Br J Anaesth, 2001; 87(1):3-11.

Masoko P, Mdee LK, Mampuru LJ, Eloff JN. Biological activity of two related triterpenes isolated from Combretum nelsonii (Combretaceae) leaves. Nat Prod Res, 2008; 22(12):1074-84.

Medzhitov R. Inflammation: new adventures of an old flame. Cell, 2010; 140:771-6.

Miriyala S, Chandra M, Maxey B, Day A, St Clair DK, Panchatcharam M. Arjunolic acid ameliorates reactive oxygen species via inhibition of $\mathrm{p} 47$ (phox)-serine phosphorylation and mitochondrial dysfunction. Int J Biochem Cell Biol, 2015; 68:70-7.

Mshana NR, Abbiw DK, Addae-Mensah I, Adjanouhoun E, Ahyi MRA, Ekpere JA, Enow-Orock EG, Gbile ZO, Noamesi GK, Odei MA, Odunlami H, Oteng-Yeboah AA, Sarpong K, Sofowora A, Tackie AN. Traditional medicine and pharmacopoeia, contribution to the revision of ethnobotanical and floristic studies in Ghana. OAU/STRC Technical Report, Addis Ababa, Ethiopia, p 67, 2000.

Nanda A, Ansari SH, Khatkar S. Arjunolic acid: a promising antioxidant moiety with diverse biological applications. Curr Org Chem, 2017; 21(4):287-93.

Obiri DD, Osafo N. Aqueous ethanol extract of the fruit of Xylopia aethiopica (Annonaceae) exhibits anti-anaphylactic and anti-inflammatory actions in mice. J Ethnopharmacol, 2013; 148(3): $940-5$.

Ododo MM, Choudhury MK, Dekebo AH. Structure elucidation of $\beta$-sitosterol with antibacterial activity from the root bark of Malva parviflora. Springerplus, 2016; 5(1):1210.

Okoye TC, Uzor PF, Onyeto CA, Okereke EK. 2014. Safe African Medicinal Plants for Clinical Studies: In Toxicological Survey of African Medicinal, Elsevier Inc. 535-55. DOI: http://dx.doi.org/10.1016/ B978-0-12-800018-2.00018-2.

Paniagua-Pérez R, Flores-Mondragón G, Reyes-Legorreta C, Herrera-López B, Cervantes-Hernández I, Madrigal-Santillán O, MoralesGonzález JA, Álvarez-González I, Madrigal-Bujaidar E. Evaluation of the anti-inflammatory capacity of beta-sitosterol in rodent assays. Afr J Tradit Complement Altern Med, 2016: 14(1):123-30.

Pierre LL, MN. Moses, Isolation and characterisation of stigmasterol and $\beta$-sitosterol from Odontonema strictum (acanthaceae). Int J Innovations Pharm Sci, 2015; 2(1):88-95.

Prieto P, Pineda M, Aguilar M. Spectrophotometric quantitation of antioxidant capacity through the formation of a phosphomolybdenum complex: specific application to the determination of vitamin E. Anal Biochem, 1999; 269(2):337-41.

Ravipati AS, Zhang L, Koyyalamudi SR, Jeong SC, Reddy N, Bartlett J, Smith PT, Shanmugam K, Münch G, Wu MJ, Satyanarayanan M, Vysetti B. Antioxidant and anti-inflammatory activities of selected Chinese medicinal plants and their relation with antioxidant content. BMC Complement Altern Med, 2012; 6;12:173.

Roach JT, Sufka KJ. Characterization of the chick carrageenan response. Brain Res, 2003; 994:216-25.

Sugimoto MA, Sousa LP, Pinho V, Perretti M, Teixeira MM. Resolution of inflammation: what controls its onset? Front Immunol, 2016; 26(7):160

Tandon VR, Verma S, Singh J, Mahajan A. Antioxidants and cardiovascular health. Int J Med Educ, 2005; 7(2):115-18.

Vasudevan M, Gunman KK, Parle M. (2007). Antinociceptive and anti-inflammatory effects of thespesia populnea bark extract. J Ethnopharmacol, 2007; 109:264-70.

Vinegar R, Schreiber W, Hugo R. Biphasic development of carrageenin edema in rats. J Pharmacol Exp Ther, 1969;166(1):96-103.

Xie X, Yang M, Ding Y, Chen J. Microbial infection, inflammation and epithelial ovarian cancer. Oncol Lett, 2017; 14(2):1911-9.

Xu C, Wang B, Pu Y, Tao J, Zhang T. Techniques for the analysis of pentacyclic triterpenoids in medicinal plants. J Sep Sci, 2018; 41(1):6-19.

Yaidikar L, Thakur S. Arjunolic acid, a pentacyclic triterpenoidal saponin of Terminalia arjuna bark protects neurons from oxidative stress 
associated damage in focal cerebral ischemia and reperfusion. Pharmacol Rep, 2015; 67(5):890-5.

Zhao D, Zheng L, Qi L, Wang S, Guan L, Xia Y, Cai J. Structural features and potent antidepressant effects of total sterols and $\beta$-sitosterol extracted from Sargassum horneri. Mar Drugs, 2016; 14(7):123.

Zhou Y, Hong Y, Huang H. Triptolide attenuates inflammatory response in membranous glomerulo-nephritis Rat via Downregulation of NF-kB signaling pathway. Kidney Blood Press Res, 2016; 41:901-10.
How to cite this article:

Ramos GF, Amponsah IK, Harley BK, Jibira Y, Baah MK, Adjei S, Armah FA, Mensah AY. Triterpenoids mediate the antimicrobial, antioxidant, and anti-inflammatory activities of the stem bark of Reissantia indica. J Appl Pharm Sci, 2021; 11(05):039-048. 